\title{
Analysis of Educational Quality Based on Quality, ServQual and Retention of Students
}

\author{
Tegowati ${ }^{1}$, Dian Palupi ${ }^{1} \&$ Yesa Cahayaning Ramadhani ${ }^{1}$ \\ ${ }^{1}$ Department of Management, Indonesian College of Economics (STIESIA) Surabaya, Indonesia \\ Correspondence: Tegowati, Department of Management, Indonesian College of Economics (STIESIA) Surabaya, \\ J1. menur Pumpungan No. 30 Sukolilo East Java, 60118, Indonesia. Telp: 031-594-7505. E-mail: tegowati@ \\ stiesia.ac.id
}

Received: November 6, 2019; Accepted: January 5, 2020; Published: May 22, 2020

The research is financed by Indonesian College of Economics (STIESIA) Surabaya, Indonesia.

\begin{abstract}
This study analyzed the influence of ServQual (service quality) on satisfaction and student retention. The sample used was 175 STIESIA Surabaya students using non probability sampling called, accidental sampling. Data analysis used Structural Equation Modeling (SEM) with AMOS 21 software. Based on the discussion of the hypotheses proposed in this study, the conclusions are as follows: 1). There is a positive influence between ServQual on satisfaction. This is based on the results of the parameter coefficient output. It is known that the relationship of the ServQual construct to satisfaction is significant at $0.001(\operatorname{sign} p=* * *)$ with a standardized parameter coefficient of 0.735 . Thus, if ServQual is good, students will be satisfied, and vice versa if ServQual is bad, students will not be satisfied. 2) There is a positive effect of satisfaction on student retention. This is based on the results of the output coefficient parameter construct relationship satisfaction to student retention significant at $0.001(\mathrm{p}=0.001)$ and standardized parameter coefficient of 0.513 . Thus if student satisfaction is high then student retention is also high, and vice versa if satisfaction is low then student retention is also low. 3) There is no influence between ServQual on student retention indicated by the output parameter coefficient at $0.001(\mathrm{p}=0.132)$ This proves that loyalty cannot be created through service quality, but through satisfaction first. thus, it can be said that satisfaction has a mediating effect between ServQual and Student Retention.
\end{abstract}

Keywords: ServQual (Service Quality), satisfaction, student retention

\section{Introduction}

By always prioritizing the quality of the learning system, a university will be able to achieve success through the positive expectations of students in higher education. Student's positive expectations can be used to measure college success. If students have positive expectations, the higher education services can be said to be successful. After students' positive expectations for education services can be fulfilled, universities are expected to maintain and increase positive expectations (satisfaction) of students to create student loyalty to the campus. With student loyalty, students will feel confident to choose the same campus if later students wish to continue to a higher level.

This is in accordance to the conclusion of "Onditi and Wechuli (2017), that service quality in higher education has a significant influence on student satisfaction and therefore higher education institutions should put in place mechanisms to collect student feedback to enable them to determine the service quality dimensions of interest to their students so that they can make the necessary improvements on the relevant service quality dimensions". Cheng and Zabid (2013) "suggested that perception of service quality is significantly related to customer satisfaction which in turn generates positive customer loyalty". Satisfaction and loyalty will be able to make students eager to learn, which in turn can become qualified graduates of the university, and can be equally beneficial for both students and universities. Thus, it is very important to give maximum satisfaction to students. This is supported by "Cheng and Zabid (2013), stating that satisfaction has a significant effect on student loyalty". Also, "student satisfaction has positive influence to student loyalty (Kunanusorn and Puttawong, 2015)". 


\section{Literature Review}

\subsection{Service Quality Model}

Shahin and Dabestani (2010) state that, the concept of service quality is an essential element that contributes to the success of a service origination. The service quality model / SERVQUAL model (service quality) is a model that is used as a reference to analyze the source of quality problems and understand ways to improve service quality. "Despite being criticized, the SERVQUAL model has proven to be a popular model that has been used in various service industries to evaluate service quality (Emari et al. 2010)".

In general, customers tend to compare the perceived service with the expected service. If the service is assumed to be smaller than the expected service, then the customer will feel disappointed. Conversely, if the service assumption is greater than the expected service, the customer will be satisfied. If there are other benefits that are added value, then consumers are very satisfied. According to Parasuraman, et al. (1988 in Tjiptono and Chandra, 2016: 137), there are five main dimensions of service quality arranged in the order of their relative importance as follows:

1. Reliability, related to the company's ability to provide accurate services from the first time without making any mistakes and delivering its services in accordance with the agreed time.

2. Responsiveness, with regard to the willingness and ability of employees to help customers and respond to their requests, and inform when services will be provided and then provide services quickly.

3. Assurance, namely the behavior of employees is able to foster customer trust in the company and the company can create a sense of security for its customers. Guarantees also mean that employees are always polite and always master the knowledge and skills needed to handle every customer's question or problem.

4. Empathy, means that the company understands the problems of its customers and acts in the interests of customers, and gives personal attention to customers and has a comfortable operating hours.

5. Physical Evidence (Tangibles), regarding the attractiveness of physical facilities, equipment, and materials used by the company, as well as the appearance of employees.

These five factors were then developed on the scale of Servqual (service quality) in the service sector. According to Mahmud (2012: 63), in general there are 6 educational services, namely:

a) Information service. Information services are provided in oral and written form. Oral information can be obtained through face-to-face direct contact, while written information can be provided through various guidebooks such as brochures, banners, pamphlets, bulletin boards, websites and others.

b) Infrastructure services. Infrastructure services are the provision of services in the form of providing infrastructure or physical facilities such as: school buildings, libraries, laboratories and others.

c) Administrative services. Administrative services include payment of SPP and the making of certificates and so on.

d) Guidance services. Guidance services begin with a school orientation program, guidance in overcoming difficulties especially learning difficulties and also personal problems, educational and teaching guidance (KBM), and scientific practice guidance.

e) Services for developing talents and interests and skills. Services for developing talents and interests and skills are carried out through extracurricular activities for students.

f) Welfare services. Among the forms of welfare services to students are the provision of scholarships to outstanding students, especially the poor and the provision of waivers of SPP.

\subsection{Satisfaction}

"Satisfaction is a feeling of pleasure or disappointment that arises because someone compares the perceived performance of the product (or result) to their expectations (Kotler and Keller 2009: 138)". Customer satisfaction may drive loyalty, but it may not be a very reliable, and definitely not the only determinant of loyalty (Faullant et al. 2008). Faullant et al., (2008) found out that both image and overall satisfaction are important to influence the degree of customer loyalty.

To measure customer satisfaction, there are three methods that can be used (Kotler and Keller, 2009: 140):

a) Periodic surveys (tracking customer satisfaction directly and also asking additional questions to measure repurchase intentions and the possibility or willingness of respondents to recommend a company and brand to others). 
b) The rate of customer loss (observing the level of customer loss and contacting customers who stop buying or switching to other suppliers to find out why).

c) Mysterious shoppers (employing mysterious shoppers to act as potential buyers and report on the strong and weak points they experience in buying company products and competing products).

For enhancing service loyalty, "service satisfaction plays the most influential role, followed by technical quality, functional quality, and vice switching costs. Moreover, satisfaction mediates the relationship between service quality and service loyalty (Quoquab et al., 2016)".

\subsection{Student Retention}

Customer retention is a form of loyalty or loyalty to a company or service provider that is more related to customer behavior to stay with service providers which is characterized by customer repurchase behavior. For education services, the repurchase in question is choosing the same campus to continue their studies. The need to increase student retention from the beginning of admission to graduation is important in managing higher education, because recruiting new students is far more expensive than maintaining existing students.

In the perspective of educational institutions, "student loyalty is often referred to as student perseverance or student retention (Roberts \& Styron, 2009)". "Garland (in sembiring, 2014), also uses the expression 'perseverance' in the same connotation as student loyalty". This implies that loyalty, perseverance or retention has the same meaning as the concept of customer loyalty in consumer behavior discourse.

\subsection{Conceptual Framework and Hypotheses Development}

This research analysis model consists of 3 latent variables, namely satisfaction, retention and servqual. This study will analyze the effect of servqual on satisfaction, the effect of servqual on retention, and the effect of satisfaction on moderating the relationship between servqual and retention. Based on the research objectives to be achieved, the research analysis model is organized as follows:

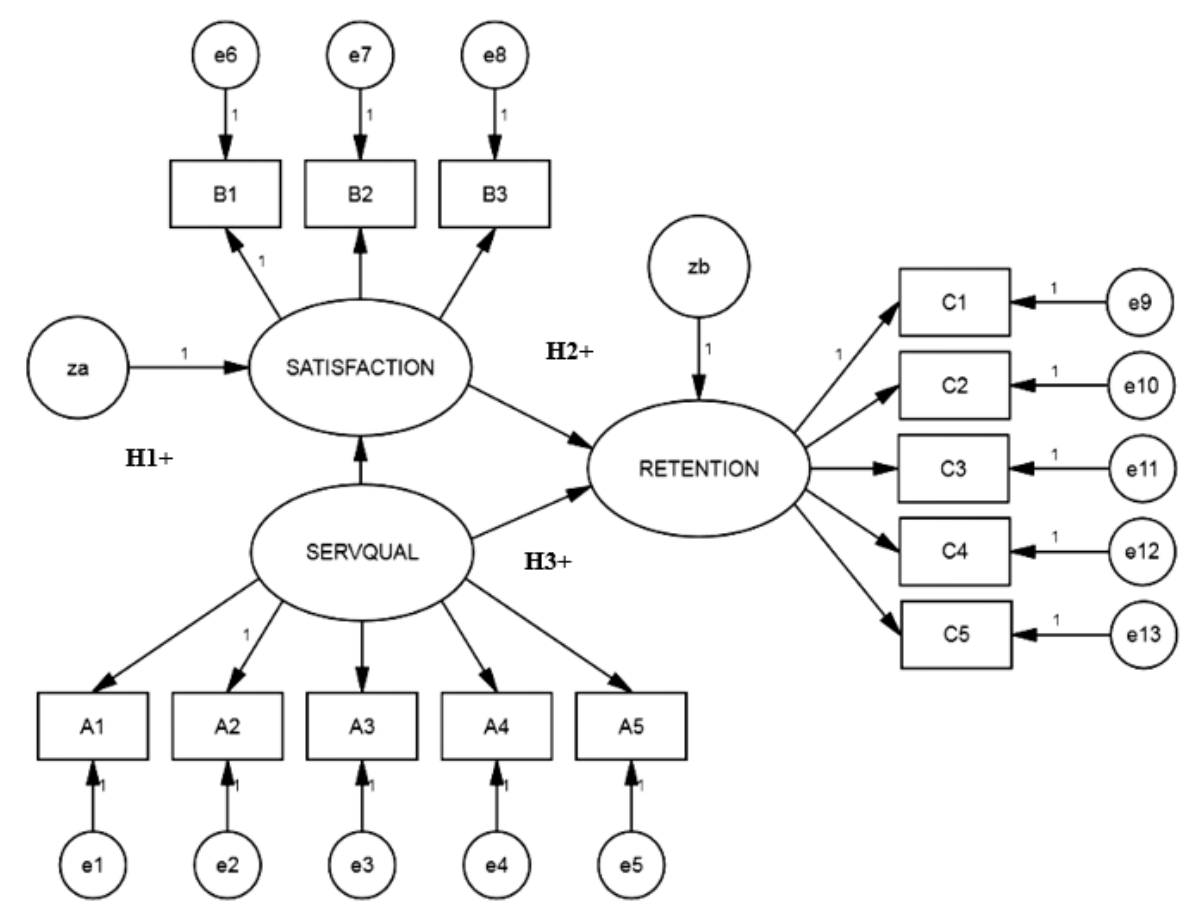

Figure 1.1 Conceptual Framework of Variable Relations

\subsection{Formulation of the Hypothesis}

1. There is a positive effect of ServQual (service quality) on satisfaction (student satisfaction).

2. There is a positive effect of satisfaction (student satisfaction) on student retention (student retention).

3. There is a positive effect of ServQual (service quality) on student retention (student retention). 
Dimensions in measuring servqual refer to Parasuraman, et al. (1988 in Tjiptono and Chandra, 2016: 137) namely Reliability (4 indicators), Responsiveness (4 indicators), Assurance (4 indicators), Empathy (5 indicators), and Tangibles (10 indicators). The satisfaction dimension refers to Irawan, 2008: 9 as follows:

a. Overall service satisfaction; b. Recommend to other parties; $c$. Will use services again. The five dimensions used to measure student retention in this study refer to the Sembiring (2014) research, namely completion, recommendation, further study, keeping relations and contribution. so the total indicator used is 35 .

\section{Method}

\subsection{Sampling Technique}

The researcher used the number of questions method, which is to determine the sample through the number of question items in the questionnaire. "The trick is to multiply 5x the number of question items (Husein, 2008 in Wiyono, 2011)". The number of items in the questionnaire used in this study were 35 items. So, the total of samples $5 \times 35=175$ samples. The validity and reliability of the questionnaire will be measured. There are four measures of construct validity, namely Convergent Validity, Variance Extracted, Reliability and Discriminant Validity. While reliability there are two ways that can be used, namely Composite (Construct) Reliability and Variance Extracted.

\subsection{Data Collection Technique}

The technique of data collection is done by distributing questionnaires. Distributing questionnaires to respondents with a nonprobability sampling approach, namely accidental sampling. The measurement scale used is Likert scale of 1-5. The questionnaire was distributed to STIESIA Surabaya strata 1 students who were or were already studying semester 4 and were still active in college when sampling was conducted. Researchers have the notion that students who are or have taken semester 4 studies, have experienced education services at STIESIA for two years and are considered to be able to feel how good the quality of services provided by STIESIA. From the distribution of questionnaires to 175 respondents, namely students of Surabaya Indonesian Economics College who were or had taken semester 4 studies. However, only 159 questionnaires returned for data analysis.

\subsection{Data Analysis Technique}

Data were analyzed using SEM techniques with AMOS 21 software. In this technique, a confirmatory test and a validity reliability test were analyzed. Then the full model SEM analysis and SEM assumption test were performed

\section{Results}

\subsection{Exogenous ServQual Construct Confirmation Test}

The standardized value of the loading estimate is above 0.50 , except for the A1 indicator which has a value below 0.50 which is 0.469 . Thus the A1 indicator must be dropped (discarded). Exogenous construct test results (ServQual) have convergent validity values (standardized loading estimate values) are already above 0.50 then observed (indicators) servqual are good, except indicator A1 which has values below 0.50 namely 0.469 . Thus the indicator A1 must be dropped (discarded). The loading factor of the ServQual variable is presented in table 1 as follows:

Table 1. Standardized Regression Weights Results for Exogenous Constructions

\begin{tabular}{llr}
\hline & & Estimate \\
\hline A1 $<---$ & Servis_Quality & .469 \\
A2 $<---$ & Servis_Quality & .710 \\
A3 $<---$ & Servis_Quality & .690 \\
A4 $<---$ & Servis_Quality & .750 \\
A5 <--- & Servis_Quality & .510 \\
\hline
\end{tabular}

After a modified confirmatory test is performed (without including the A1 indicator), the results of the standardized loading estimate indicators forming the Servqual variable have shown to be unidimensional or valid because all the values have been above 0.5 . These results indicate that the construct can be processed with a full model. 
Table 2. Standardized Regression Weights Results for Modified Exogenous Constructions

\begin{tabular}{llr}
\hline & & Estimate \\
A2 <--- & Servis_Quality & .689 \\
A3 <--- & Servis_Quality & .717 \\
A4 <--- & Servis_Quality & .746 \\
A5 <--- & Servis_Quality & .508 \\
\hline
\end{tabular}

\subsection{Confirmatory Test Between Endogenous Constructs Student Satisfaction and Retention}

Confirmatory Factor Analysis endogenous constructs carried out on two variables, namely student satisfaction and retention. These two endogenous variables are mutually exclusive. The results of the endogenous construct indicator load factor values indicate that there is 1 indicator in the endogenous construct that is invalid, namely the $\mathrm{C} 1$ indicator with a loading factor value of 0.278 (less than the minimum loading factor value requirement of 0.5 ) so the $\mathrm{C} 1$ indicator must be dropped from the analysis.

Table 3. Results of Standardized Regression Weights of Endogenous Constructions

\begin{tabular}{llr}
\hline & & Estimate \\
\hline B1 $<---$ & Satisfaction & .759 \\
B2 $<---$ & Satisfaction & .897 \\
B $3<---$ & Satisfaction & .652 \\
$\mathrm{C} 5<---$ & Retention & .797 \\
$\mathrm{C} 4<---$ & Retention & .841 \\
$\mathrm{C} 3<---$ & Retention & .515 \\
$\mathrm{C} 2<---$ & Retention & .664 \\
$\mathrm{C} 1<---$ & Retention & .278 \\
\hline
\end{tabular}

Based on an analysis of the endogenous construct of student satisfaction and retention that has been modified (without including the $\mathrm{C} 1$ indicator) a valid standardized loading estimate is obtained because it is above 0.50 . In the following table 1.12, the loading factor for each indicator of endogenous construct modification is presented:

Table 4. Standardized Regression Weights Results of Modified Endogenous Constructions

\begin{tabular}{llr}
\hline & & Estimate \\
\hline $\mathrm{B} 1<---$ & Satisfaction & .759 \\
$\mathrm{~B} 2<---$ & Satisfaction & .896 \\
$\mathrm{~B} 3<---$ & Satisfaction & .653 \\
$\mathrm{C} 2<---$ & Retention & .655 \\
$\mathrm{C} 3<---$ & Retention & .519 \\
$\mathrm{C} 4<---$ & Retention & .840 \\
$\mathrm{C} 5<---$ & Retention & .807 \\
\hline
\end{tabular}

Based on the modified analysis (without including the $\mathrm{C} 1$ indicator), the standardized loading estimate is valid because it is above 0.50 . These results indicate that the construct can be processed with a full model.

4.3 Full Model SEM Analysis

SEM analysis of the full model is done by entering confirmatory tested indicators: 


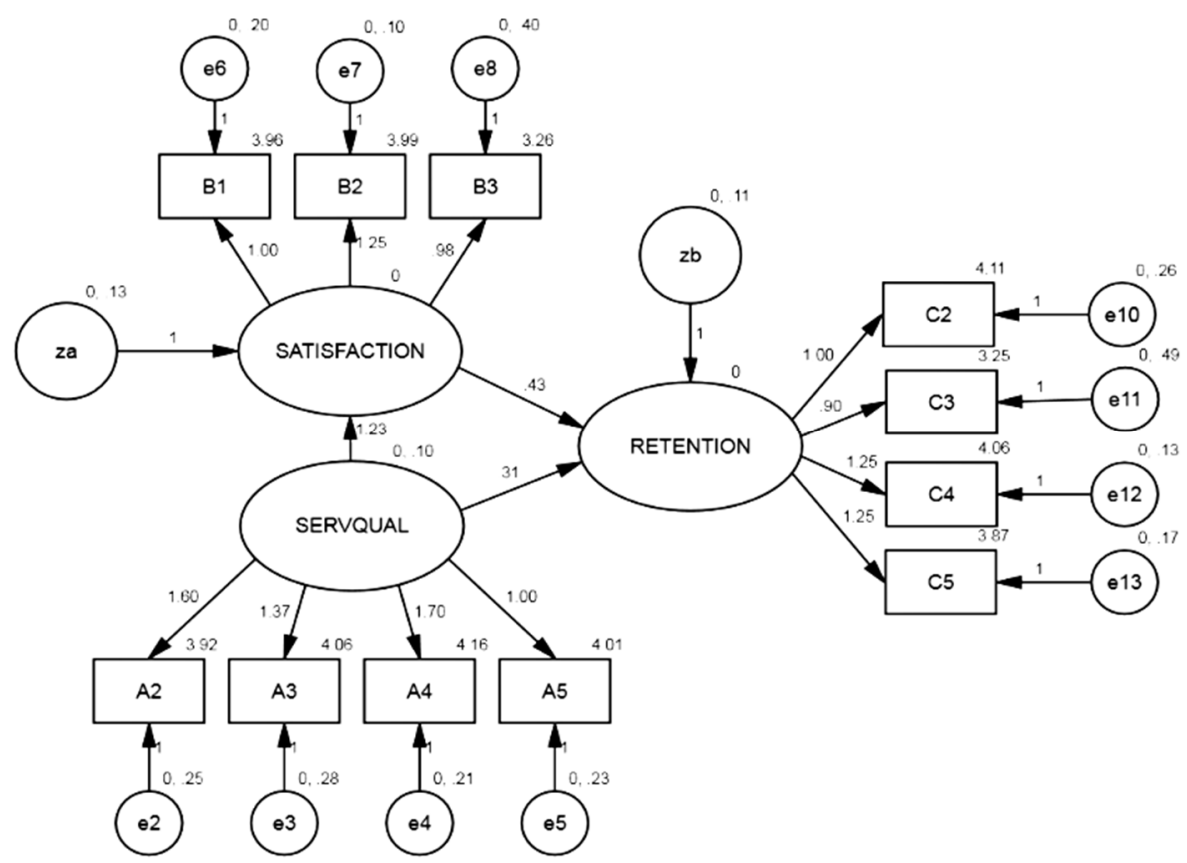

Figure 1.2 Full Structural Model

The output results show goodness-fit value is quite good, Chi-square value $=100,330$ probability 0,000 . The values of GFI, AGFI, CMIN / DF, TLI, and CFI are all quite good. Thus the model is quite in accordance with the empirical data.

Table 5. Standardized Regression Weights Full Model

\begin{tabular}{llll}
\hline & & & Estimate \\
\hline SATISFACTION & $<---$ & SERVQUAL & .735 \\
RETENTION & $<---$ & SATISFACTION & .513 \\
RETENTION & $<---$ & SERVQUAL & .221 \\
B1 & $<---$ & SATISFACTION & .766 \\
B2 & $<---$ & SATISFACTION & .900 \\
B3 & $<---$ & SATISFACTION & .636 \\
A5 & $<---$ & SERVQUAL & .554 \\
A4 & $<---$ & SERVQUAL & .759 \\
A3 & $<---$ & SERVQUAL & .632 \\
A2 & $<---$ & SERVQUAL & .708 \\
C2 & $<---$ & RETENTION & .660 \\
C3 & $<---$ & RETENTION & .504 \\
C4 & $<---$ & RETENTION & .843 \\
C5 & $<---$ & RETENTION & .808 \\
\hline
\end{tabular}

\subsection{Test Validity and Reliability}

\subsubsection{Convergent Validity}

Based on the results of the standardized loading estimate, all statistically significant loading factors and loading values are above 0.50 .

4.4.2 Variance Extracted

AVE values are calculated for each latent construct: 


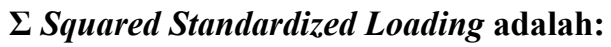

- $\quad$ Servqual $=0,708^{2}+0,632^{2}+0,759^{2}+0,554^{2}=1,784$

- Satisfaction $=0,766^{2}+0,900^{2}+0,636^{2}=1,801$

- $\quad$ Student Retention $=0,660^{2}+0,504^{2}+0,843^{2}+0,808^{2}=2,053$

\section{Variance Extracted Calculation}

- ServQual $=\frac{1,784}{1,784+2,215}=0,446$

- Satisfaction $=\frac{1,801}{1,801+1,198}=0,601$

- Student Ret. $=\frac{2,053}{2,053+2,048}=0,501$

The calculation of AVE above shows that all constructs have good values because they are above 0.50 . However the ServQual construct has a value below 0.50. This is because the loading value for the ServQual construct is still below 0.70 , namely the A5 indicator. A loading value below 0.70 will pull the AVE value down or below the value 0.50 (Ghozali 2011: 139). But in this study the A5 indicator was not removed from the analysis because the loading value was above 0.50 (already fulfilling the minimum loading value requirements).

4.4.3 Construct Reliability

\section{Sum Standardized Loading:}

- ServQual $=0,708+0,632+0,759+0,554=2,653$

- Satisfaction $=0,766+0,900+0,636=2,302$

- Student Retention $=0,660+0,504+0,843+0,808=2,815$

\section{$\Sigma$ Measurement Error:}

- $\quad$ ServQual $=0,498+0,601+0,423+0,693=2,215$

- Satisfaction $=0,413+0,190+0,595=1,198$

- Student Retention $=0,430+0,254+0,710+0,658=2,048$

\section{Reliability Calculation}

ServQual $=\frac{(2,653)^{2}}{(2,653)^{2}+2,215}=0,760$

Satisfaction $=\frac{(2,302)^{2}}{(2,302)^{2}+1,198}=0,815$

Student Ret. $=\frac{(2,815)^{2}}{(2,815)^{2}+2.048}=0,795$

Reliability calculation shows that for all constructs has a value above the cut-off value of 0.70 . Thus it can be concluded that the indicators in this study have good reliability.

\section{Discriminant Validity}

Servqual $=\sqrt{0,446}=0,667$

Satisfaction $=\sqrt{0,601}=0,775$

Student Retention $=\sqrt{0,501}=0,708$

Each latent construct has discriminant validity is quite good, this can be seen from the square root value of AVE $(\sqrt{ } A V E)$ each latent constellation higher value than the correlation value between constructs, except the value in the second column AVE square root for latent constructs ServQual is 0.667 , the value is smaller than the correlation between satisfaction 0.735 . Similar to the Servqual construct, the calculation of the variance extracted is still below 0.50 because the loading factor values are not all above 0.70 , so the value of the discriminant validity ServQual construct also has $\sqrt{ } A V E$ a lower value than the correlation value between construct. 


\subsubsection{SEM Assumption Test}

\section{Evaluation of Data Normality}

From the output of normality data, it can be concluded that there is no evidence that the data used has an abnormal distribution, because the value of the critical ratio skewness value is below 2.58 . Therefore the assumption of normality has been fulfilled and the data used in this study is feasible to use in subsequent estimates.

Table 5. Assessment of normality

\begin{tabular}{lrrrrrr}
\hline Variable & $\min$ & $\max$ & skew & c.r. & kurtosis & c.r. \\
\hline C5 & 2.000 & 5.000 & -.045 & -.233 & -.474 & -1.220 \\
C4 & 3.000 & 5.000 & -.064 & -.329 & -.750 & -1.930 \\
C3 & 1.000 & 5.000 & .174 & .897 & .579 & 1.490 \\
C2 & 2.000 & 5.000 & -.384 & -1.975 & -.005 & -.012 \\
$\mathrm{~A} 2$ & 2.000 & 5.000 & -.303 & -1.562 & -.052 & -.135 \\
$\mathrm{~A} 3$ & 2.000 & 5.000 & -.425 & -2.189 & .280 & .721 \\
$\mathrm{~A} 4$ & 2.000 & 5.000 & -.351 & -1.806 & -.599 & -1.541 \\
$\mathrm{~A} 5$ & 3.000 & 5.000 & .001 & .007 & .058 & .148 \\
$\mathrm{~B} 3$ & 1.000 & 5.000 & .045 & .233 & .338 & .869 \\
$\mathrm{~B} 2$ & 1.000 & 5.000 & -.456 & -2.349 & .577 & 1.484 \\
$\mathrm{~B} 1$ & 2.000 & 5.000 & -.392 & -2.016 & .256 & .658 \\
Multivariate & & & & & 18.152 & 6.767 \\
\hline
\end{tabular}

\section{Outlier Evaluation}

The criteria used are to pay attention to the Chi-square value of degree of freedom 35, which is the number of indicator variables at the significance level $p<0.001$. Mahalanobis distance value $\chi 2(35 ; 0.001)=66.62$. Thus if the value of the expensive distance distance in this study is greater than 66.62 is multivariate outliers. Because in this study there are no expensive distance values greater than 66.62 , it can be concluded that there are no outliers in the data.

\subsubsection{Hypothesis Testing}

\section{Test of Hypothesis I}

Hypothesis 1: There is a positive influence between Servqual (service quality) on satisfaction (student satisfaction). From the output of the parameter coefficient, it is known that the construct relationship of Servqual (service quality) to satisfaction (student satisfaction) is significant at $0.001(\operatorname{sign} \mathrm{p}=* * *)$ with standardized parameter coefficient of 0.735 . Thus it can be said that hypothesis 1 in this study is acceptable.

\section{Test of Hypothesis II}

Hypothesis 2: There is a positive effect of satisfaction (student satisfaction) on student retention (student retention). Based on the output of the parameter coefficient, it is known that the relationship of construct satisfaction (student satisfaction) to student retention (student retention) is significant at $0.001(\mathrm{p}=0.001)$ with a standardized parameter coefficient of 0.513 . Thus it can be said that hypothesis 2 in this study is acceptable.

\section{Test of Hypothesis III}

Hypothesis 3: There is no positive effect of servqual (service quality) on student retention (student retention). Based on the output of the parameter coefficient it is known that the relationship between the Servqual construct (service quality) to student retention (student retention) is not significant at $0.001(\mathrm{p}=0.132)$ with the standardized parameter coefficient of 0.221 . Thus it can be said that hypothesis 3 in this study is not accepted the truth.

\section{Discussion}

The test results on hypothesis 1 show there is a positive influence between Servqual (service quality) on satisfaction (student satisfaction). This means that good quality service will satisfy STIESIA Surabaya students. If the quality of STIESIA services as a provider of higher education services in Surabaya can be given well and continues to be improved, it will have a positive impact on the progress and sustainability of STIESIA Surabaya. The results of hypothesis 1 in this study support the research of "Maulana et al. (2012) which suggests that there is a significant 
influence between SERVQUAL (Tangible, Reliability, Responsiveness, Assurance, Empathy) and student satisfaction. This means that the higher (positive) Servqual (service quality) given by STIESIA to STIESIA students, the higher the satisfaction (student satisfaction)".

While the results of hypothesis 2 test states there is a positive influence between satisfaction (student satisfaction) on student retention (student retention). This shows that the satisfaction felt by students will make students loyal to STIESIA Surabaya. The results of this study support "Fikri et al (2016), which states that satisfaction has a significant effect on student loyalty".

Then the results of hypothesis 3 test states that there is no positive effect of Servqual (service quality) on student retention (student retention). Although the results are not significant, there is still an effect of 0.221 . This proves that loyalty cannot be created through service quality, but through satisfaction first. The results of this study support the research conducted by "Maulana et al (2012) which states that there is no significant effect between servqual on student loyalty". Interviews conducted by researchers on students stated that even though the quality of services provided was good, but not fully able to make students choose STIESIA again as their campus to continue their studies to a higher level because students want to find other insights on the new campus later. However, not a few STIESIA students choose to continue their studies to a higher level at STIESIA.

\section{Conclusion}

1. There is a positive influence between Servqual (service quality) on satisfaction (student satisfaction). This is based on the output of the parameter coefficients. It is known that the construct relationship of Servqual (service quality) to significant satisfaction (student satisfaction) is 0.001 (sign of $\mathrm{p}=* * *$ ) with standardized parameter coefficient of 0.735 . Thus if ServQual (service quality) is good then students will be satisfied, and vice versa if ServQual (service quality) is bad then students are not satisfied.

2. There is a positive effect of satisfaction (student satisfaction) on student retention (student retention). This is based on the output of the parameter coefficient relationship construct satisfaction (student satisfaction) to student retention (student retention) significant at $0.001(\mathrm{p}=0.001)$ with a standardized parameter coefficient of 0.513. Thus if satisfaction (student satisfaction) is high then student retention (student retention) is also high, and vice versa if satisfaction (student satisfaction) is low then student retention (student retention) is also low.

3. There is no influence between Servqual (service quality) on student retention (student retention). This is shown by the output of the parameter coefficient at $0.001(\mathrm{p}=0.132)$ with the standardized parameter coefficient of 0.221 . This proves that loyalty cannot be created through service quality, but through satisfaction first. Thus, student retention will be high if the quality of service is also good and supported by high satisfaction as well. Conversely, student retention will be low if the service quality is perceived as low and unsatisfactory for students.

\section{Acknowledgments}

We extend our thanks to research institute and community service (LPPM) STIESIA Surabaya.

\section{References}

Cheng, B. L., \& Md. Zabid, A. R. (2013). Service Quality and the Mediating Effect of Corporate Image on the Relationship between Customer Satisfaction and Customer Loyalty in the Malaysian Hotel Industry. Gadjah Mada International Journal of Business, 15(2), 99-112. https://doi.org/10.22146/gamaijb.5474

Cronin, Jr. J. J., \& Taylor, S. A. (1994). SERVPERF versus SERVQUAL; Reconciliation performance based and $\begin{array}{lllll}\text { perceptions minus expectations. Journal of Marketing, } & 58(1), & 125 .\end{array}$ https://doi.org/10.1177/002224299405800110

Darsono, L. I., \& Junaed, C. M. (2006). An Examination of Perceived Quality, Satisfaction, and Loyalty Relationship Applicability of Comparative and Noncomparative Evaluation. Gadjah Mada International Journal of Business, 8(3), 323-342. https://doi.org/10.22146/gamaijb.5612

Emari, H., Iranzadeh, S., \& Bakhshayesh, S. (2010). Determining the dimensions of service quality in banking industry: Examining the Grönroos's model in Iran. Journal of Compilation, 1-5. https://doi.org/10.3923/tasr.2011.57.64

Faullant, R., Matzler, K., \& Füller, J. (2008). The impact of satisfaction and image on loyalty: the case of Alpine ski resorts. Managing Service Quality, 18(2), 163-178. https://doi.org/10.1108/09604520810859210

Ghozali, I. (2011). “Aplikasi Analisis Multivariate Dengan Program SPSS”. Badan Penerbit Universitas 
Diponegoro. Semarang.

Kotler, P., \& dan Keller, K. L. (2009). Manajemen Pemasaran. Edisi 13, Jilid 1, Erlangga. Jakarta.

Kunanusorn, A., \& Puttawong, D. (2015). The Mediating Effect Of Satisfaction On Student Loyalty To Higher Education Institution. European Scientific Journal, 1, 449-463.

Mahmud, M. (2012). Manajemen Mutu Perguruan Tinggi. PT Raja Grafindo Persada, Jakarta.

Onditi, E. O., \& Wechuli, T. W. (2017). Service Quality and Student Satisfaction in Higher Education Institutions: A Review of Literature. International Journal of Scientific and Research Publications, 7(7), 328-335.

Quoquab, F., Abdullah, N. L., \& Mohammad, J. (2016). Investigating the Effects of Consumer Innovativeness, Service Quality and Service Switching Costs on Service Loyalty in the Mobile Phone Service Context. Gadjah Mada International Journal of Business, 18(1), 21-53. https://doi.org/10.22146/gamaijb.9286

Roberts, J., \& Styron, D. R. (2009). Student Satisfaction And Persistence: Factors Vital To Student Retention. Research in Higher Education Journal, 1-18.

Sembiring, M. G. (2014). Modeling The Determinants Of Student Retention In Distance Education Institutions. International Journal of Continuing Education and Lifelong Learning, 6(2), 15-28.

Shahin, A., \& Dabestani, R. (2010). Correlation analysis of service quality gaps in a four-star hotel in Iran. International Business Research, 3(3), 40-46. https://doi.org/10.5539/ibr.v3n3p40

Tjiptono, F., \& dan Chandra, G. (2016). Service, Quality dan Satisfaction. Edisi 4. Andi Offset. Yogyakarta.

\section{Copyrights}

Copyright for this article is retained by the author(s), with first publication rights granted to the journal.

This is an open-access article distributed under the terms and conditions of the Creative Commons Attribution license (http://creativecommons.org/licenses/by/4.0/). 